\title{
The Effects of Social Protection Program on Food Consumption and Poverty in Khyber Pakhtunkhwa, Pakistan
}

\begin{abstract}
Aneesa $^{1}$, Muhammad Tariq ${ }^{2}$, Farah Khan ${ }^{3}$
Abstract

This study examines the effects of Unconditional Cash Transfers scheme of Benazir Income Support Program on household food consumption pattern and poverty in the District Mardan, Khyber Pakhtunkhwa, Pakistan. For this purpose, data has been collected randomly through a comprehensive questionnaire from 383 selected beneficiaries located in two villages, namely, Kot Doulat Zai and Batagram of the District Mardan. The methods of Flexible Linear Approximate Almost Ideal Demand (LA-AIDS) and poverty index have been used for the estimation of results. Firstly, investigating the impact of cash transfers on household consumption, it is found that cash transfers increased their expenditures on cereals, meat and decreased on pulses, dairy products and fruits/vegetables. Secondly, analyzing the role of cash transfers in household's poverty reduction, the results showed that household consumption shortfall reduced from $21 \%$ to $14 \%$ and their consumption deprivation poverty decreased from $42 \%$ to $31 \%$. These findings suggest that the Unconditional Cash Transfers scheme is affecting the household consumption pattern and has reduced their poverty. Hence, further increase in the amount of cash transfers, formulation and implementation of effective policies in this regard can improve the standard of living of the poor and the needy people in District Mardan and in the province of Khyber Pakhtunkhwa.
\end{abstract}

Keywords: BISP, unconditional cash transfers, LA-AIDS model, Engel curve

\section{Introduction}

Cash transfers schemes are one of the measures used for tackling poverty and improving the standard of living of the people of low and middle-income countries (Holmes, Slater \& Bhuvanendra, 2013). Over the last decade, cash transfers are in-

1 MS Scholar Department of Economics, Abdul Wali Khan University Mardan

Email:aneesazaman1991@gmail.com

2 Assistant Professor, Department of Economics, Abdul Wali Khan University Mardan

Email: tariq_noor@awkum.edu.pk

3 Assistant Professor, Women University Mardan, KP-Pakistan Email: drfarah@wumardan.edu.pk

\begin{tabular}{ll} 
ARTICLE HISTORY & \\
27 Feb, 2018 Submission Received & 6 Apr, 2018 First Review \\
\hline 16 July, 2018 Second Review & 18 Oct, 2018 Third Review \\
\hline 1 Nov, 2018 Accepted
\end{tabular}

1 Nov, 2018 Accepted 
creasingly being adopted as an important element of national strategies for protection against economic shocks and enabling the people to invest in themselves and their children. Currently, around the world, almost 130 low and middle-income countries implemented at least one unconditional social transfer programme including poverty-targeted transfers and old-age pensions, etc. Such schemes are increasingly popular in Sub-Saharan Africa, where 40 out of 48 countries now have an unconditional cash transfer programme. In addition, 63 countries have at least one conditional cash transfer programme which is considered an important pillar of their economic development policies (Honorati, Gentilini \& Yemtsov 2015).

Cash transfers are a form of social safety net programme, which include both conditional and unconditional income transfers to the poor people in a country. It is the direct payment of a fixed amount of money to the deserving people in order to fulfill their minimum consumption needs and bring improvement in their living conditions (Arnold, Conway \& Greenslade, 2011). Cash transfers increase household income which they spend on food items and for improving the quality and diversity of their diet. Cash transfer programme contributes to the food requirements of the poor people through two mechanisms. First, it increases their production and productivity by stimulating local agricultural production and non-agricultural activities. Second, it affects local markets by generating increased demand which in turn triggers a supply response of local producers (Arnold et al. 2011).

Cash transfers programme can support household access to food through different ways. A $10 \%$ increase in the household income improves their food security by $5 \%$ as measured by calories available for consumption (GOP, 2012). However, once access to calories reaches a threshold level, attention switches to food quality and household caloric acquisition continues to rise but at a much slower rate. When household diversifies their diet, it increases their consumption of fruits, vegetables, animal products, cereals and meat. A household access to food depends on a number of factors including food prices, household income and assets, etc. An increase in household income can improve their food security through access to food (Huang, Fletcher \& Raunikar ,1981). Moreover, poor communities are very sensitive and vulnerable to shocks, i.e. natural disasters, crop failure, etc. which cause transitory food insecurity because of sudden increase in prices and lower their real income and purchasing power (Holmes, Slater \& Bhuvanendra, 2013). Hence social protection programmes, such as cash transfers can be very effective in such situations.

Over the years, poverty remained one of the major unmanageable issues in Pakistan. The Government of Pakistan (2015A) Multidimentional Poverty Index (MPI) report showed that $39 \%$ of Pakistanis are living in multidimensional $1^{4}$ poverty. Out

4 Multidimensional poverty is consisting of three dimensions i.e. education, health and standard of livings. It is specifically a product of two components incidence of poverty and intensity of poverty. Whereas, the incidence of poverty measures the percentage of people who are multi dimensionally poor and intensity of poverty indicates the percentage of deprived people. 
of this, $54.3 \%$ are living in urban areas, whereas $9.3 \%$ in rural areas. The report further stated that $73 \%$ poor are living in FATA, 71\% in Balochistan, 31\% in Punjab, 43\% in Gilgit-Baltistan and Sindh, 25\% in Azad Jammu and Kashmir and 49\% in Khyber Pakhtunkhwa.

Benazir Income Support Programme (BISP) was initiated by the Pakistan People Party Government during July 2008. So far, the programme is the biggest social safety net programme in the history of the country (BISP, 2017). Multiple social protection schemes were launched under the umbrella of BISP with the objective of protecting the poor families against the rapid rise in food, grain and fuel prices which reached to a 30-year highest level in 2008. The main aim of the programme was to eradicate poverty and improve the lives of marginalized and deprived population in the country (Government of Pakistan, 2015B). Initially, during the fiscal year 2008-09, the government allocated a budget of Rs.34 billion for the programme with a targeted coverage of 3.5 million families, who were almost $15 \%$ of the country's population. The allocated amount had been increased up to Rs. 70 billion with 5 million targeted beneficiaries during 2009-10. The allocation of budget was further increased to Rs. 50 billion and Rs. 75 billion during 2011-12 and 2013-14 respectively. The disbursement was increased to Rs.96.65 billion and Rs. 115 billion during 2015-16 and 2016-17 respectively. So far, Rs. 412 billion has been distributed amongst the poor families all over the country. Moreover, the total number of BISP beneficiaries increased from 1.7 million in the year 2009 to 5.29 million at the end of March 2016. The main purpose behind the increase in the allocation of budgets was to improve the living standard of almost $40 \%$ of population, who are living below the poverty line in the country (Government of Pakistan, 2017).

The Unconditional Cash Transfer (UCT) scheme is the core programme of BISP and since its establishment in 2008; the government has allocated and transferred a large amount of money to the needy people in the country. The key objective of BISP Cash transfer scheme, was to help the poor families in the fulfillment of their basic needs and supporting them during inflationary and crises periods. Initially, the monthly cash transfers to the poor was fixed to Rs. 1000. This amount was increased to Rs.1200 per month during July 2013. It was further increased to Rs.1500 per month in July 2014. The cash transfers was further increased to Rs. 4700 per quarter, during 2015-16 (Government of Pakistan, 2017).

Keeping in view all this, it is important to investigate the contribution of BISP towards the better standard of living of poor people in Khyber Pakhtunkhwa. This study is designed to examine the impact of Unconditional Cash Transfers on the consumption pattern and poverty of households in District Mardan. So far only a limited number of studies have been carried out for examining the 
effectiveness of BISP in Pakistan. Nayab and Farooq (2014) conducted a study on the effectiveness of BISP cash transfers in all the four provinces by using Pakistan Panel Household Survey (PPHS) data of 2010. Similarly, Hassan (2015) investigated the causes of failure of all social protection programs including BISP initiated by the government of Pakistan since 1947. Moreover, Khan, Akhtar, Khan and Adnan (2017) assessed the role of Cash Grant Scheme of Benazir Income Support Program in poverty alleviation in the three selected villages namely Jori Banda, Char Banda and Babini of District Mardan. Furthermore, Ambler and Brauw (2017) analyzed the impact of Pakistan's BISP cash transfers on women's decision-making power within households in Pakistan.

This study has several contributions to the literature. First, the main contribution is that it is the first ${ }^{5}$ study which investigates the effects of social protection on food consumption and poverty in Mardan, KP-Pakistan. Similarly, the application of LAAIDS and poverty index approaches for examining the relationship between cash transfer, food consumption and poverty is another distinguishing feature of the study. Moreover, the empirical model of the study has been developed on the Engel Curve theory which further strengthens the overall importance of the study. The sample size of this study is relatively large compared to previous related studies which may give more cogent empirical results. Therefore, this study equally contributes to the existing body of literature on the relationship between social protection programme and poverty in the context of Mardan, KP, which can be extended not only to the other parts of KP but also to Sindh, Baluchistan, Punjab provinces and other developing countries in order to ensure maximal social welfare.

\section{Literature Review}

The literature shows, that a series of studies have been conducted for investigating the contribution of different social protection programmes, i.e. conditional and unconditional cash transfers both in the developed and developing countries. They have empirically tested whether cash transfer programmes can play any role in the food and non-food consumption, health and nutrition and poverty reduction of the beneficiaries' household. The results of all of these previous studies are inconclusive regarding the positive and negative role of social protection programmes in various countries.

Neenan and Devis (1977) investigated the impact of food stamp programme on

5 Khan et al. (2017) conducted a study "The role of cash grant scheme of Benizir Income Support Programme in poverty alleviation in three rural areas of District Mardan". However, the study has no theoretical background. Moreover, data have been collected from only 70 beneficiaries. And all the data has been analyzed only through simple tables. 
low income household in rural Florida using income expenditure survey. The results showed that income, family size and food stamp programme affected food consumption positively. The study further indicated that participant household spends $\$ 38.41$ in a month on food against non-participant, who spends only $\$ 33.28$. Chavas and Yeung (1982) analyzed the effects of food stamp programme on food consumption in Southern United States by using consumer expenditure survey 1972-1973. It is concluded that food stamp increased family expenditures for food items like cereals, bakery, beef, pork, veal, and dairy products. Phillips and Price (1982) conducted a study for investigating the effects of the food stamp programme and cash transfer on the demand for food in United States. The study results showed that food stamp programme increased household food demand more than twice after receiving bonus stamps. Ezemenari and Subbarao (1999) studied the effect of Jamica's food stamp programme on poverty and welfare by using Jamaican survey of 1989-1991. The results showed that cash transfer increased household marginal propensity of consumption and improved their welfare. The results further show that the programme reduced headcount poverty and poverty gap. Tabor (2002) mentioned that the economic benefits of cash transfer programs are greater against providing assistance in kind. On one side direct cash transfers do not distort prices. On the other hand because of its less operating cost procedure, cash transfers programmes can be effectively manageable. In another study, Maitra and Ray (2003) analyzed the effect of cash transfers on household expenditure patterns and poverty in South Africa using income expenditure survey data of 1999-2000. The findings of the study revealed that cash transfers received by the households' through different sources affected their expenditure pattern differently and played an important role in the reduction of poverty in the country. Van de Walle (2003) conducted a study for testing the role of Vietnam's public safety net programmes. The study used Vietnam's Living Standard Survey data for the analysis. It is found that government's safety net programmes put minor effects on the people. These programmes did not play a significant role in the protection of the poor class during the crises time. Similarly, Rawling and Rubio (2003) evaluated the impact of conditional cash transfer programme on the socio-economic status of the people in Latin American countries. It is concluded that cash transfers contributed to human capital accumulation, increased school enrolment and attendance rate and reduced poverty in all the Latin American countries. Baronets (2004) investigated the effects of cash transfers i.e. noncontributory pension programs on the households in Brazil and South Africa, using households' surveys data collected during 2002. For the analysis one thousand, one hundred and eleven (1111) households were selected from South Africa and 1006 households from Brazil. The results showed that non-contributory pension schemes promoted human capital formation and supported the poor class. Moreover, these non-contributory pension programmes reduced long term poverty amongst the pension recipient households' in both countries. Skoufias and Maro 
(2006) examined the role of conditional cash transfers in adult work incentive and poverty in Mexico. The results indicated that cash grant schemes reduced both short and long-term poverty reduction through greater investment in education, health and nutrition. Shehzad (2011) investigated the influences of Benazir Income Support Programme (BISP) on women's empowerment and poverty in Pakistan. They collected primary data through stratified random sampling method from the two provinces namely, Sindh and Punjab. The findings of the study showed that that cash transfers under BISP increased daily expenditures on food items, supported in payment of utility bills, health expenditure, children education and travelling expenses. Moreover, it was concluded that because only women were the receiving the cash amount. Therefore, the decision to spend the cash was at their own choice, enhanced their bargaining power. The study suggested that the government should improve evaluation and management system of BISP for making the programme more effective in the country. Malik, Kiran and Alam (2013) studied the role of BISP programme in poverty reduction in District Peshawar. The study concluded that BISP helped in the reduction of poverty of the beneficiaries in Peshawar. Nayab and Farooq (2014) studied the role of Benazir Income Support Programme in poverty reduction in Pakistan. For this purpose, Pakistan Panel Household data, 2010 has been used. The study used Propensity Score Method and Binary Logistic Regression for the estimation of results. The study found insignificant relationship between cash transfers and poverty reduction. Moreover, the cash received by the household were mainly spent on food and non-food items and didn't contribute to their poverty reduction. Dinbabo and Agbann (2014) examined the relationship between social grants and poverty reduction at household level in Ghana. The study concluded, that social grants increased consumption, health care and school enrolment rate, while decreased child labor in Ghana. Azam, Iqbal and Tayyab (2014) analyzed the role of Zakat in the economic development of Pakistan. According to the results, Zakat is an important instrument for the promotion of the social welfare of the people in the country. Naqvi, Sabir, Shamim and Tariq (2014) conducted a study for examining the effect of Benazir Income Support Programme (BISP). They concluded that cash transfers provided some kind of relief for the household in their daily expenditures on food items, education and health. Khan and Hasan (2016) investigated the role of social protection system in Bangladesh. It is found that the present social protection system failed to play an effective role in improving the standard of living of the poor people and providing them sustainable income support. Tiwari et al. (2016) analyzed the impact of cash transfer program on food security in Africa. They concluded that cash transfers increased the quality and quantity of food and reduced food insecurity. Hjelm et al. (2017) found out that unconditional cash transfer programs improved per capita expenditures, food security and asset ownership in Zambia. Kaul (2018) studied the effects of Indian Public Distribution System on the household consumption in 
India. The findings of the study were that the programme showed small but positive effects on the household calories from all food groups.

From the above discussion it is clear that a large number of studies have tested the effectiveness of the cash grant programmes in various countries. Similarly, in Pakistan the effectiveness of the BISP cash transfers have also been investigated by a limited number of studies. However, this study is different from the previous studies in several aspects. First, unlike the previous studies, this study examines the role of BISP Unconditional Cash Transfers in the household food consumption and poverty reduction in District Mardan, Khyber Pakhtunkhwa. Second, the empirical model of the study has been developed on the basis of theory of Engel curves. Moreover, the theory has been in case of normal goods, necessities and luxury items which is another contribution of the study to the current literature. Furthermore, with and without cash transfers approach has been used for the collection of information from the beneficiaries. Finally, LA-AIDS and Poverty Index have been used for the estimation of the results. Hence, the following hypotheses can be made keeping in view the objectives of the study. Mardan.

Hypothesis $1_{1}$ : Cash Transfers positively affect household consumption pattern in District

Hypothesis 2: Cash Transfers has negative relationship with household poverty in District Mardan.

\section{Theoretical Framework}

The relationship between consumption of commodities and income change is embodied in the economic theory of Engel curves. The Engel theory was presented by Ernest Engel, a German Statistician and Economist, during 1857. In the literature, "there are two varieties of Engel curves. One is the Budget share Engel curve which describes how the proportion of household income spent on certain good varies with income. Alternatively, Engel curve can also describe how real expenditure varies with household income”. According to Working (1943) and Lesser (1963), Engel curves are specifically used for examining the relationship between total expenditures and expenditures on specific goods. They further added that Engel curve can also be derived in case of different types of goods. A hypothetical model of the Engel curves in case of normal goods, necessities and luxuries is given in figure 1 as below.

Figure 1 shows the Engel Curves in case of normal goods, necessities and luxuries. The diagram shows that in case of normal goods, the shape of the Engel Curve slopes upward, which depicts that when the total expenditures/income of the consumer increases, their expenditures on the normal goods also increases. The curve further 
Type III: Normal Goods

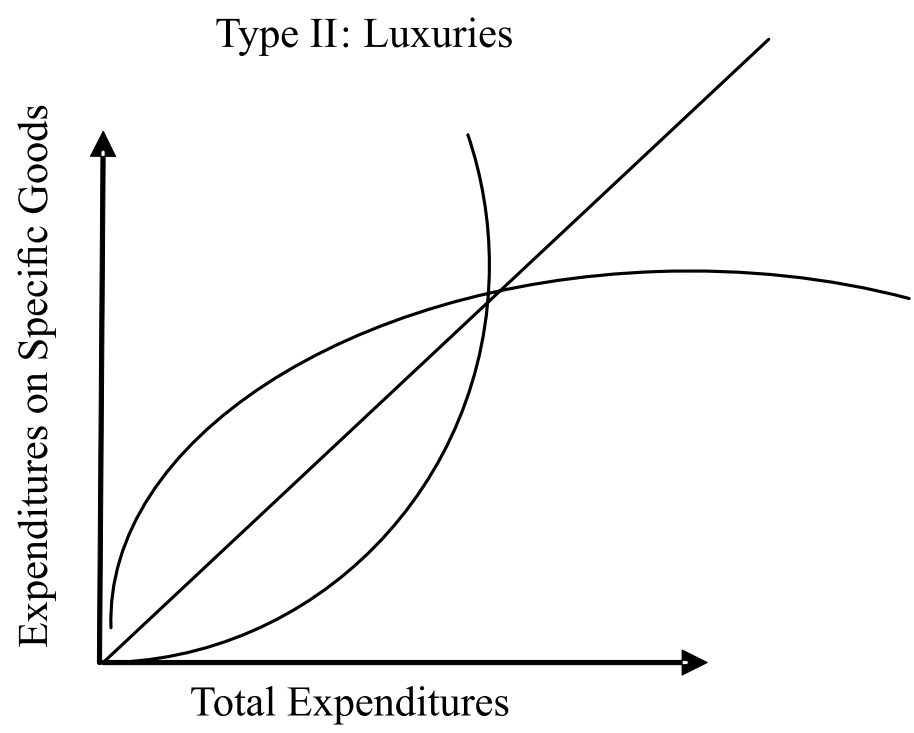

Type I: Necessities

Figure 1: Engel Curve Various Shapes

shows that the consumers continuously increase their consumption of the normal goods at all level of incomes. And because of this, the shape of the Engel Curve does not change. While in case of luxuries, the shape of the Engel Curve is convex. The curve shows that initially, the rise in income brings less proportionate increase in their expenditures on the luxuries. However, once the income level of the consumer reached to a certain level. After that they begin to consume a large quantity of luxuries for maintaining their living standard and class in the society. Finally, the Engel Curve for necessities goods is given which is concave in shape. This shows that with the increase in consumer income, they increase their consumption of the necessity good. However, once they crossed a certain level of income, they bring reduction in their consumption of the necessity good.

Mathematically, it can be written as follows;

Type I-Necessities: $\mathrm{P}_{1} \mathrm{q}_{1}=\mathrm{e}_{1}=\frac{V_{i} Y}{K_{1}+Y}$

Type II-Normal Goods: $\mathrm{P}_{2} \mathrm{q}_{2}=\mathrm{e}_{2}=m y+c$

Type III-Luxuries: $\mathrm{P}_{3} \mathrm{q}_{3}=\mathrm{e}_{3}=\mathrm{n}\left(\mathrm{Y}-\mathrm{e}_{1}\right)+\mathrm{r}=\frac{n\left(Y^{2} K_{1}-V_{1}\right) Y}{K_{1}+Y}+r$

In equation- $-1, \mathrm{P}_{1}, \mathrm{q}_{1}$ and $\mathrm{e}_{1}$ are the price, quantity and expenditure of necessities such as cereals. Similarly, in equation-2, $\mathrm{P}_{2}, \mathrm{q}_{2}$ and $\mathrm{e}_{3}$ stand for price, quantity and 
expenditure of normal goods such as oil, sugar, lighting, etc. Whereas, in equation-3, $\mathrm{P}_{3}, \mathrm{q}_{3}, \mathrm{e}_{3}$ represent price, quantity and expenditure of luxuries such as clothing and shelter. Moreover, $\mathrm{Y}$ is income or total expenditure and $v, k$ and $r$ are Engel curve parameters.

Figure 2 below shows the Engel Curve for Necessities, consumption deprivation or poverty curve and consumption deprivation or poverty area in case of necessities. The Engel Curve shows the relationship between total expenditures (i.e. given on horizontal axis) and expenditure on necessities (i.e. given on vertical axis on the left side of the diagram). The curve shows that expenditure on necessities increase with an increase in income, reaches a maximum level and then declines. The point where it reaches to maximum level is taken as a poverty threshold. While consumption

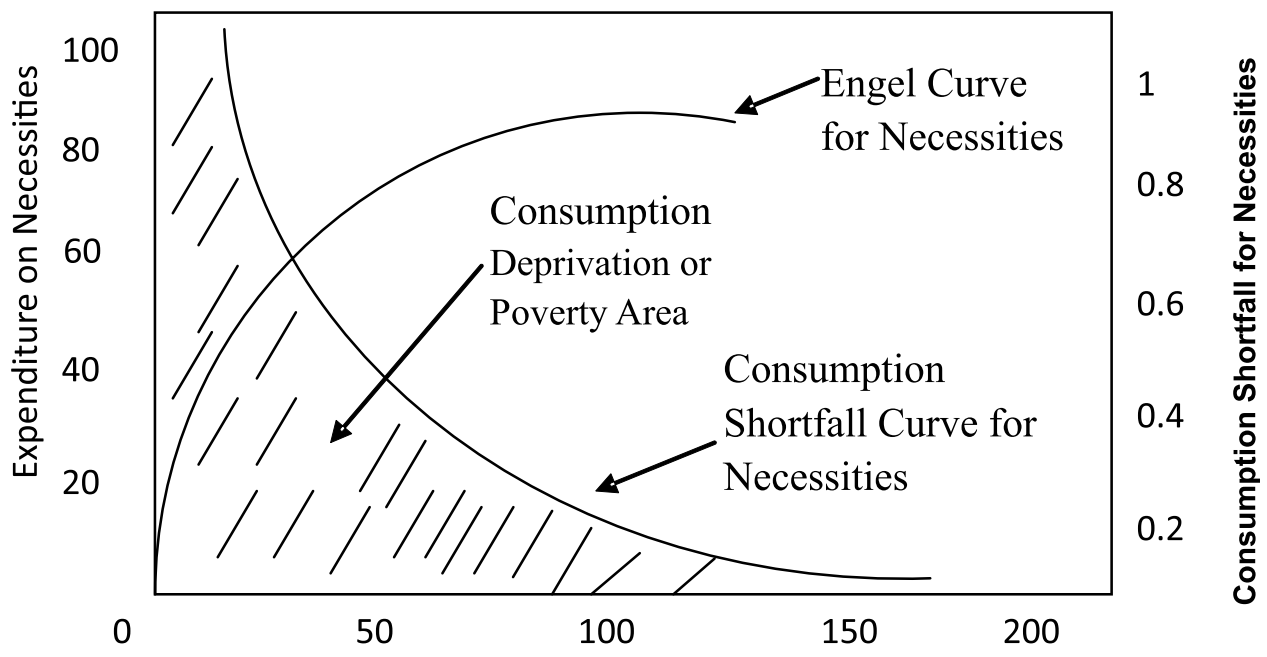

\section{Total Expenditures}

Figure 2: Consumption Shortfall Curve in Case of Necessities

below this maximum level is called consumption deprivation.

The shape of the Engle curve here is concave. This shows that consumption shortfall is a decreasing function of income. As income increases, consumption shortfall/ shortage decreases and vice versa. The consumption shortfall is measured on a scale of 0 to 1 which is given on right side vertical axis of the diagram. A movement towards zero shows that consumption shortfall decreases and movement towards 1 shows that consumer consumption shortfall increases. Whereas, the area behind the consumption shortfall curve shows the consumption deprivation or poverty of the consumers.

It can be seen from equation 1 mentioned above, the saturation level of consump- 
tion can be determined from $\mathrm{q}_{1}{ }^{*}$ by dividing $\mathrm{V}_{1}$ (i.e.saturation level for consumption commodity) by the price of that commodity $\left(\mathrm{P}_{1}\right)$. It can be easily verified that $\mathrm{K}_{1}$ corresponds to the level of income needed to consume half of $\mathrm{V}_{1}$. Hence, from equation 1 , the following equation is derived given in equation 4 as below.

$$
\mathrm{K}_{1}=\left(\frac{V_{1}}{e_{1}}\right) Y-Y
$$

Equation 4 states that, whatever will be the income and the corresponding expenditure on an essential commodity, such as cereal $\mathrm{e}_{1}$, the difference between a proportional increase with income to reach $\mathrm{V}$ and the actual income-virtual income gap is the same. The parameter $K_{1}$ thus has the interpretation of an income gap. Now consumption shortfall is as follows:

$$
\mathrm{S}(\mathrm{Y})=\frac{1}{V_{1}}\left[V_{1}-\frac{V_{1} Y}{K_{1}+Y}\right]=\frac{K_{1}}{K_{1}+Y}
$$

It can be seen that the consumption shortfall (S) is a decreasing function of income. A critical level $\lambda$, such as whenever the consumption shortfall exceeds $\mathrm{e}_{1}$, there is consumption deprivation ( $\lambda$ may be set equal to 0 or $1 / 2)$. One can then define a society's consumption deprivation as the expected or average proportion of persons whose consumption shortfall exceeds $\lambda$.

The mean proportion of persons whose consumption short-fall exceeds $\lambda$, Consumption Deprivation Index (D) can then be written as

$$
D=P(S>\lambda)=P\left(\frac{q^{*}-q}{q^{*}}>\lambda\right)=\int P\left[\left(\frac{q-q}{q}\right)>\lambda \mid Y\right] f(Y)
$$

Where $(\mathrm{A} / \mathrm{y})$ denotes probability of event $\mathrm{A}$, given the income is $\mathrm{y}$, and $\mathrm{f}(\mathrm{y})$ denotes the density function associated with the income distribution, and $\mathrm{q}^{*}$ is the maximum possible consumption. It may be noted that $\mathrm{P}\left(\mathrm{q}^{*}-\mathrm{q} / \mathrm{q}^{*}\right)>\lambda \mid \mathrm{Y}$ is a decreasing function of Thus consumption deprivation can be represented by a measure as follows:

$$
D=\int h(Y) f(Y) d Y
$$

Where $\mathrm{h}(\mathrm{Y})$ ) is a decreasing function of and $\mathrm{Y}$ and $\mathrm{f}(\mathrm{Y})$ is the density function associated with the income distribution. In particular, one can define consumption deprivation index among all persons with incomes less than or equal to y by

$$
D Y^{*}=\int_{0}^{Y^{*}} h(Y) f(Y) d
$$

The deprivation function $\mathrm{h}(\mathrm{Y})$ ) represents the probability that a person with income $y$ has a consumption less than $\mathrm{q}^{*}(1-\lambda)$. As income $(\mathrm{Y})$ decreases $\mathrm{h}(\mathrm{Y})$ increases. Hence, poverty can simply be defined where $h(Y)=S(Y)$ as shown in equation (5). It shows the proportional consumption shortfall at income level from the maximum consumption. 


\section{Empirical Models}

The empirical estimation of Engel curves can be performed in many ways. Prais and Houthakker (1971) concluded that the widely used double logarithmic (QUAIDS) and the semi-logarithmic(LA-AIDS) performed better than the others in terms of goodness of fit. The LA-AIDS model has several theoretical advantages over other models such as being an arbitrary first order approximation to any demand system, the axioms of choice are satisfied, aggregates perfectly over consumers without invoking parallel linear Engel curves. Its functional form is consistent with known household budget data, simple to estimate, avoids the need for non-linear estimation, and provides a means to test the empirical validity of the theoretical restrictions of homogeneity and symmetry (Deaton and Muellbauer, 1980). For estimating the effect of cash grant on household consumption pattern, LA-AIDS method has been used.

\subsection{Empirical model for cash transfers and household's consumption}

Deaton and Muellbaur (1980) developed the Almost Ideal Demand System from an expenditure function with Price Independent Generalized Logarithmic preferences to derive. The system of LA-AIDS demand equation in budget share. The form is given as

$$
w_{i}=a_{i}+\sum_{j=1}^{n} \gamma i_{j}+\operatorname{In} p_{j}+\beta_{1} \operatorname{In}\left(\frac{x}{p}\right)+e_{i}
$$

where $\mathrm{w}_{\mathrm{i}}$ is the budget share of goods, $\mathrm{p}_{\mathrm{j}}$ is the price of good $j, x$ is expenditure, $P$ is a price index approximated by the Stone Price $\operatorname{Index}, \operatorname{In}(P)=\sum_{j} \mathrm{w}_{j} \operatorname{In}\left(\mathrm{p}_{\mathrm{j}}\right) n$ is the number of goods, $\ln$ represents natural logarithm and $\alpha_{\mathrm{i}}, \beta_{\mathrm{i}}, \gamma_{\mathrm{ij}}$ are parameters. To account for the household characteristics, equation (9) is augmented with household specific socio-economic and demographic characteristics using the following relationship proposed by Pollak and Wales (1978).

$$
\alpha_{i}=\alpha_{i}+\sum_{j} \delta_{i j} Z_{j}
$$

In equation $10 \mathrm{Z}_{\mathrm{j}}$ is a matrix of socio-economic variables and $\delta_{\mathrm{ij}}$ is the vector of parameters. The socio-economic variables include household size and literacy of household head. Household size is the number of household members, a dummy variable for literacy of the household head, illiterate being the omitted category. Dummy variables are equal to one when the phenomenon exists and zero otherwise, e.g. literacy equals one when the household head is literate, otherwise zero. Substituting in the Equation (9) yields:

$$
w_{i}=a_{i}+\sum_{j=1}^{n} \gamma i_{j}+\operatorname{Inp} p_{j}+\beta_{1} \operatorname{In}\left(\frac{x}{p}\right)+\sum_{j=1}^{n} \delta_{i j} Z_{j}+e_{i}
$$

Equation (11) is the socio-economic flexible LA-AIDS (Agbola, 2003). Equation 
(11) is estimated for BISP beneficiaries in District Mardan. The budget shares and prices included in equation (11) are for five food commodities: cereals, dairy products, pulses, meat and fruits/vegetables. The theoretical restrictions on the demand function are imposed during estimation. These restrictions include the following:

\section{Adding-up:}

$$
\sum_{i}^{n} a i * i=1 \sum_{i}^{n} \gamma i j=0 \sum_{i}^{n} \beta i j=0
$$

\section{Homogeneity}

$$
\sum_{i}^{n} \gamma i j=0
$$

\section{Symmetry}

$$
\gamma_{\mathrm{ij}}=\gamma_{\mathrm{ji}}
$$

Using equation (10), uncompensated (Marshallian), compensated (Hicksian) and expenditure elasticity can be derived. The uncompensated price elasticity for good $i$ with respect to good $j$ is:

$$
e_{i j}=\frac{\delta_{i j}-\beta_{i}}{w_{i}}-\delta_{i j}
$$

Compensated price elasticity for good $i$ with respect to $\operatorname{good} j$ is:

$$
e_{i j}=\frac{\gamma_{i j}}{w_{i}}+w_{j}-\delta_{i j}
$$

Where $\delta_{\mathrm{ij}}$ is the Kronecker delta and it equals one for own price and zero for cross-price elasticity. The expenditure elasticity $\left(\mathrm{E}_{\mathrm{i}}\right)$ is:

$$
E i=1+\frac{\beta_{i}}{w_{i}}
$$

The LA-AIDS model has been estimated using seemingly unrelated regression. Two weeks recall method is used for the collection of information from the beneficiaries regarding consumption of various food items. If beneficiaries do not consume a particular food item then the price for that item is missing. These missing prices are replaced by average prices. All food items are divided into five major groups on the basis of their common characteristics. Imposing the additive property of the expenditure function makes the variance and covariance matrix singular and one of the equations needs to be omitted to estimate the LA-AIDS. The expenditure equation for "fruits and vegetables" is omitted and the coefficients for the omitted equation are derived using the theoretical conditions imposed on the estimation process. However the coefficients estimated using LA-AIDS are invariant to the omitted equation. 


\subsection{Empirical model for cash transfers and household's poverty}

Let us consider the Engel curve for a necessity such as cereals which can be represented by equation 12 as follows:

$$
C=P_{c} q_{c}=\frac{\left(q_{c} p_{c}\right) Y}{K+Y}=\frac{V Y}{K+Y}
$$

Where $\mathrm{q}^{*} \mathrm{P}_{\mathrm{c}}=\mathrm{V}, \mathrm{V}$ is the saturation expenditure on cereals, $\mathrm{q}^{*} \mathrm{c}$ being the saturation quantity. Let $\mathrm{P}_{\mathrm{c}}$ and $\mathrm{q}_{\mathrm{c}}$ denote the price and quantity of cereals while $\mathrm{P}_{\mathrm{nc}}$ and $\mathrm{q}_{\mathrm{nc}}$ denote the price and quantity of the composite commodity non-cereals (all commodities other than cereals).

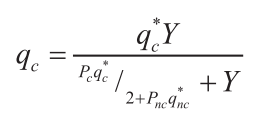

Where $q_{t}^{\prime} P_{n c}$ is the non-cereal expenditure associated with a cereal expenditure of $P_{c}^{P q^{*}} / 2$. Further, it can also be noted that equation (12) derived from the Engel curve, is homogenous of degree zero in prices and income. Thus, it is the demand function for cereals. It is clear from the above reformulation of the Engel Curve how the price of cereal, price of non-cereal and income affect the real consumption of cereals. Thus, the short term effect on poverty (STEP) of changes in prices and income can be easily calculated employing our poverty index. This can be seen more explicitly by writing the poverty associated with a household with income as it can be seen from equation (14) as below.

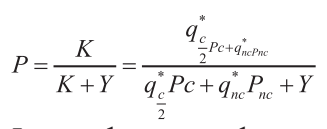

It can be seen that

$$
\begin{aligned}
& \frac{\partial P}{\partial P_{c}}=\frac{Y q_{\frac{c}{2}}^{*}}{(K+Y)^{2}}> \\
& \frac{\partial P}{\partial P_{n c}}=\frac{Y q_{n c}}{(K+Y)^{2}}> \\
& \frac{\partial P}{\partial Y}=\frac{-K}{(K+Y)^{2}}>
\end{aligned}
$$

Equations (15) to (17) show the partial effects of changes in price of food, price of non-food, and income on the poverty respectively. These are termed as short-term effects on poverty (STEP).

\section{Results and Discussion}

This section shows the information about the data, sampling method and estimation results. First, section 5.1 explains the data, data collection process and sample size selection. After that section 5.2 presents the estimation results. The details are given as below. 


\subsection{Data and sample size}

District Mardan is administratively subdivided into three tehsils i.e. Mardan Tehsil, Takht Bhai Tehsil and Katlang Tehsil. Presently, the total numbers of BISP cash transfer scheme beneficiaries in all the three tehsils are approximately 80,000. For data collection, first Tehsil Mardan has been selected out of all the three tehsils. After that union council Kot Doulat Zai has been chosen out of all 48 union councils of Tehsil Mardan. Then data has been collected from the beneficiaries ${ }^{6}$ located in two villages namely Kot Doulat Zai and Batagram of Kot Doulat Zai union council. For the selection of appropriate sample size, normal approximation method has been used (Walpole, 1982).

$$
\begin{aligned}
& n=\frac{\alpha^{2} p(1-p)}{e^{2}} \\
& n=\frac{(1.96)^{2}(0.52)(0.48)}{(0.05)^{2}} \\
& n=383 \\
& n=\text { Sample size } \\
& . \alpha=\text { Confidence level } \\
& P=\text { Proportion of sample respondents in the ith village } \\
& e=\text { Margin of error }
\end{aligned}
$$

The following formula of Cochran (1977) has been applied for the proportional allocation and selection of 383 beneficiaries, from and between the two selected villages.

$\mathrm{n}_{\mathrm{i}}=\left(\mathrm{N}_{\mathrm{i}} / \mathrm{N}\right)^{*} \mathrm{n}$

$\mathrm{n}_{i}=$ Number of sampled respondents in $\mathrm{i}^{\text {th }}$ village

$\mathrm{N}_{\mathrm{i}}=$ Total number of beneficiaries of BISP in ith village

$\mathrm{N}=$ Total number of beneficiaries of BISP in the study area

$\mathrm{n}=$ Required sample size

The number of respondent selected from each village through proportional allocation method is given in table. 1 , as follows:

The BISP beneficiaries receive the cash grant after every three months. Hence, data

6 Because the socio-economic characteristics and living styles of all the beneficiaries are almost similar in all three tehsils. For this reason data has been collected only from the beneficiaries of selected villages of Tehsil Mardan. However, 
Table1: Number of Respondents in Kot DoulatZai Union Council Mardan

\begin{tabular}{|c|c|c|c|}
\hline District & Selected Villages & No of Beneficiaries & Sample Size \\
\hline \multirow{2}{*}{ Mardan } & KotDoulatzai & 1500 & 198 \\
\cline { 2 - 4 } & Batagram & 1400 & 185 \\
\hline \multirow{2}{*}{ Total } & - & 2900 & 383 \\
\hline
\end{tabular}

was collected during the stipulated time period of three months from 383 respondents after they received the cash payments. The respondents were selected on the basis of convenience sampling method. For data collection a well structured questionnaire has been designed. The questionnaire consist of all the relevant information regarding beneficiaries i.e. age, education, source of income, monthly expenditure on food before and after cash transfer to them etc.

\subsection{Estimation results}

The demographic profiles of the beneficiaries showed that out of a total of 383 beneficiaries, 202 women's age was below 35 years, 128 women age was in the range of $35-50$ years and 53 were above 50 years. Moreover, $62.7 \%$ were married, $19.6 \%$ were widows, $19.6 \%$ were divorced and $3 \%$ were separated. Similarly, $82.3 \%$ beneficiaries' family size was in the range of 0 to $5,16.7 \%$ were in the range of 6 to 10 , and $1.1 \%$ were above 10 members. Out of all of these beneficiaries, $61.4 \%$ were living in a joint family system, $28.5 \%$ in nuclear and $10.2 \%$ in extended family system. $84.4 \%$ beneficiaries were using electricity and gas facilities and $13.6 \%$ were having no access to gas and electricity. The total monthly income of the $54.8 \%$ beneficiaries was less than $3000,38.8 \%$ had a monthly income was in the range of 3000 to 6000 and $6 \%$ had monthly income greater than $6000.36 \%$ beneficiaries were working on daily wages, $33 \%$ were regular employees on fixed wages, $13 \%$ were having own farm, $8 \%$ were share croppers and $10 \%$ beneficiaries were running their own businesses. Furthermore, $52.5 \%$ beneficiaries were living in rented houses while $47.5 \%$ were having their own houses. It was also explored that $20 \%$ respondents visit BISP Tehsil Office, $9 \%$ visit NADRA office while $22 \%$ visit banks and $49 \%$ other places when they face certain issues. They also mentioned that no training programme is available for the beneficiaries for guiding them regarding the use of BISP card and funds transferring procedure, etc.

\subsubsection{Results for cash transfers and household consumption}

In the literature, for the empirical testing of Engel curves models, various techniques have been used. LA-AIDS is one of those methods used for testing the empirical validity of Engel curves. In the present study, the effect of cash transfer on household 
food consumption was tested in the framework of Engel curve theory by using Linear Approximate Almost Ideal Demand System (LA-AIDS). LA-AIDS model has been used because it satisfies all properties, assumption and theoretical restrictions of demand system. The model was estimated through Seemingly Unrelated Regression method. The reason for using Seemingly Unrelated Regression (SUR) method instead of Ordinary Least Squares (OLS) method was that in this study, system of equations was estimated instead of a single equation model. Adding up, homogeneity and symmetry conditions were imposed before the estimation of LA-AIDS. Along with the personal information, the beneficiaries were asked questions regarding their use of five food groups including cereals, dairy products, meat, pulses and fruits/vegetables. The selected food groups were consisting of basic food items which are consumed daily by both the poor and the rich. The food items are divided into five major groups on the basis of the nature and common characteristics of each commodity.

The results estimated are given in table 2. It is found out that most of the coefficients of the variables were significant. The $\mathrm{R}^{2}$ ranges from 0.25 for pulses to 0.49 for fruits and vegetables, which are not commonly low when using cross sectional data. The highest value of $\mathrm{R}^{2}$ showed that $49 \%$ variation in budget share has been explained by fruits/vegetables. Table 2 shows that household size showed a positive and significant effect on the consumption of dairy products but a negative and significant effect on the consumption of cereals, meat, pulses, fruits and vegetables. BISP beneficiaries with a literate household head consumed more cereals, meat and less of pulses, fruits and vegetables and dairy products. Increase in monthly income increased demand for cereals and decreased for dairy products and fruits/vegetables. Cash amount increased beneficiaries demand for cereals and meat and decreased for dairy products and fruits/vegetables. This shows that when the level of income of beneficiaries increases, they spend more on superior goods like cereals and meat and decreases expenditures on necessities like dairy products and fruits/vegetables. These results are not only supporting the consumption theory of Engel curves, but are also in line with the findings of the Angelucci, Attanasio and Maro (2012). By conducting a survey to investigate the impact of the Mexican conditional cash payment programme on transfers, savings and consumption, it is found that the majority of increase was observed in superior goods like meat and other similar items against necessities. The study concluded that the reason behind this is the improvement in the standard of livings of the beneficiaries, households.

\subsubsection{Estimation of price elasticities}

In economics, elasticity refers to the measurement of the response of a variable to a change in another variable. And price elasticity of demand measures the responsiveness of the quantity demanded of a good or service to a change in its own price by 
Table 2: Results of LA-AIDS Model of BISP Beneficiaries for Five Food Groups

\begin{tabular}{|c|c|c|c|c|c|}
\hline \multirow{2}{*}{$\begin{array}{c}\text { Explanatory } \\
\text { Variables }\end{array}$} & \multicolumn{5}{|c|}{ Food Groups } \\
\hline & Cereals & $\begin{array}{l}\text { Dairy Prod- } \\
\text { ucts }\end{array}$ & Pulses & Meat & $\begin{array}{c}\text { Fruits/Vege- } \\
\text { tables }\end{array}$ \\
\hline \multirow{2}{*}{$\begin{array}{c}\text { Log of Price of } \\
\text { Cereals }\end{array}$} & $0.080^{*}$ & $-0.043^{*}$ & $-0.043^{*}$ & $-0.016^{* *}$ & $-0.070^{*}$ \\
\hline & $(0.009)$ & $(0.007)$ & $(0.007)$ & $(0.008)$ & $(0.011)$ \\
\hline \multirow{2}{*}{$\begin{array}{c}\text { Log of Price } \\
\text { of Dairy } \\
\text { Products }\end{array}$} & $-0.032^{*}$ & $0.049^{*}$ & $0.049^{*}$ & -0.002 & $-0.018^{* *}$ \\
\hline & $(0.006)$ & $(0.005)$ & $(0.005)$ & $(0.005)$ & $(0.008)$ \\
\hline \multirow{2}{*}{$\begin{array}{c}\text { Log of Price of } \\
\text { Pulses }\end{array}$} & $-0.014^{*}$ & $-0.007^{*}$ & $-0.007^{*}$ & $0.025^{*}$ & -0.001 \\
\hline & $(0.003)$ & $(0.002)$ & $(0.002)$ & $(0.002)$ & $(0.004)$ \\
\hline \multirow{2}{*}{$\begin{array}{c}\text { Log of Price of } \\
\text { Meat }\end{array}$} & $-0.011^{* *}$ & 0.005 & 0.005 & -0.004 & $0.017^{*}$ \\
\hline & $(0.005)$ & $(0.004)$ & $(0.004)$ & $(0.004)$ & $(0.006)$ \\
\hline \multirow{2}{*}{$\begin{array}{c}\text { Log of Price of } \\
\text { Fruits/Vege- } \\
\text { table }\end{array}$} & $0.021^{*}$ & -0.004 & -0.004 & -0.002 & $0.072^{*}$ \\
\hline & $(0.003)$ & $(0.002)$ & $(0.002)$ & $(0.003)$ & $(0.004)$ \\
\hline \multirow{2}{*}{$\begin{array}{l}\text { Log Expendi- } \\
\text { ture }\end{array}$} & $0.235^{*}$ & $-0.097^{*}$ & $-0.097^{*}$ & $-0.026^{* *}$ & $-0.106^{*}$ \\
\hline & $(0.031)$ & $(0.022)$ & $(0.022)$ & $(0.011)$ & $(0.012)$ \\
\hline \multirow{2}{*}{$\begin{array}{l}\text { Monthly In- } \\
\text { come without } \\
\text { Cash Transfer }\end{array}$} & $0.131^{*}$ & $-0.063^{* *}$ & $-0.063^{* *}$ & -0.003 & $-0.048^{*}$ \\
\hline & $(0.037)$ & $(0.026)$ & $(0.026)$ & $(0.013)$ & $(0.014)$ \\
\hline \multirow{2}{*}{$\begin{array}{c}\text { Monthly } \\
\text { Income after } \\
\text { Cash Transfer }\end{array}$} & $0.255^{*}$ & $-0.013^{*}$ & $-0.013^{*}$ & -0.002 & $-0.092^{*}$ \\
\hline & $(0.063)$ & $(0.046)$ & $(0.046)$ & $(0.022)$ & $(0.025)$ \\
\hline \multirow{2}{*}{$\begin{array}{l}\text { Household } \\
\text { Size }\end{array}$} & $-0.001^{*}$ & $0.004^{* *}$ & $0.004^{* *}$ & $-0.000^{*}$ & $-0.001^{*}$ \\
\hline & $(0.004)$ & $(0.003)$ & $(0.003)$ & $(0.001)$ & $(0.001)$ \\
\hline \multirow{2}{*}{$\begin{array}{l}\text { Dummy for } \\
\text { Literacy }\end{array}$} & $0.010^{* *}$ & -0.012 & -0.012 & $-0.004^{*}$ & $-0.002^{*}$ \\
\hline & $(0.014)$ & $(0.010)$ & $(0.010)$ & $(0.005)$ & $(0.005)$ \\
\hline \multirow[t]{2}{*}{ Constant } & $0.421^{* *}$ & $0.336^{* *}$ & $0.336^{* *}$ & 0.276 & $0.186^{* *}$ \\
\hline & $(0.210)$ & $(0.152)$ & $(0.152)$ & $(0.076)$ & $(0.084)$ \\
\hline \multirow{2}{*}{$\begin{array}{c}\text { R - Squared } \\
\text { Chi }\end{array}$} & 0.412 & 0.292 & 0.292 & 0.255 & 0.490 \\
\hline & 268.73 & 158.29 & 158.29 & 129.90 & 386.65 \\
\hline
\end{tabular}

Author computation from survey data, 2016

${ }^{*},{ }^{* *},{ }^{* *}$ indicate significance level at $10 \%, 5 \%$ and $1 \%$ respectively

Standard Errors are given in parenthesis 
keeping other things constant (Barrientos, Velilla, Orozco, Villada \& Lezama,2018). Whereas, own price elasticity of demand refers to the percentage change in the demand of certain goods caused by a percentage change in its own price (Meng et al.2014).The estimated Marshallian own price elasticities are estimated and given in table 3. All of the own price elasticities are significant at $99 \%$ level of significance. The elasticities of most of food items are less than unity. The own price elasticities are negative showing that there is a negative relationship between quantity demanded and its price for all food items under consideration in conformity with traditional law of demand. The absolute value of price elasticities is low for fruits/vegetables and pulses and high for cereals and meat. Own price elasticities are same in case of both situations (i.e. with and without cash) for five food groups which ranges from 0.29 (fruits/vegetables) to 0.99 (cereals) indicating that all goods are normal goods and having negative price elasticities. And the magnitude of price elasticities didn't change in both situations. Insignificant cross price elasticities showed that substitution and complementary goods between food groups were not present.

Furthermore, table 3 shows that out of 20 uncompensated price elasticities, nine were substitutes having positive cross price elasticities and 11 were complements having negative cross price elasticities. Most of the cross-price elasticities are significant at 95\% and 99\% confidence levels.

Table 3: Uncompensated (Marshalian) Own Price and Cross Price elasticities of Beneficiaries

\begin{tabular}{|c|c|c|c|c|c|}
\hline Food groups & Cereals & Dairy Products & Pulses & Meat & Fruits/Vegetables \\
\hline Cereals & $-0.995^{*}$ & $-0.345^{*}$ & $-0.291^{*}$ & $-0.289^{*}$ & $0.403^{*}$ \\
\hline $\begin{array}{c}\text { Dairy Prod- } \\
\text { ucts }\end{array}$ & -0.036 & $-0.684^{*}$ & $0.094^{*}$ & $0.110^{*}$ & 0.024 \\
\hline Pulses & $-0.176^{*}$ & $-0.078^{* *}$ & $-0.593^{*}$ & $-0.003^{* * *}$ & 0.005 \\
\hline Meat & $-0.104^{* *}$ & 0.061 & -0.036 & $-0.799^{*}$ & $0.181^{*}$ \\
\hline $\begin{array}{c}\text { Fruits/Vege- } \\
\text { tables }\end{array}$ & $-0.064^{* *}$ & $0.073^{*}$ & $0.092^{*}$ & $0.085^{*}$ & $-0.294^{*}$ \\
\hline
\end{tabular}

Source: Author Computations from survey data, 2016

*, **, *** shows significance at $10 \% 5 \%$ and $1 \%$ respectively

\subsubsection{Estimation of expenditure elasticities}

Expenditure elasticity is the measurement of the responsiveness of expenditure on or consumption of product to a given change in the real income by keeping all other things constant. The estimated expenditure elasticities from LA-AIDS for five food groups are reported in table 4 . They are ranged from 0 and 1 . The highest bud- 
get share for cereals and meat showed that cereals and meat are the main food items used by beneficiaries and its demand is inelastic. The magnitude of these elasticities shows the weekly purchasing power of the beneficiaries. The findings showed that they were unable to purchase even their basic necessities of life. Pulses, dairy products and fruits/vegetables are normal goods whose demand changes with a change in income but less than proportionately. These findings exhibit that BISP beneficiaries in different situation (with and without cash) showed different consumption pattern. They change their consumption pattern both quantitatively and qualitatively as a result of change in income. The results indicated that expenditure elasticities of the beneficiaries for some food items are high in situation with cash income and low without cash income. While, for some food items it was low as compared to without cash situation. The coefficient estimated for total food expenditure, support a strong income effect in case of changing budget share. The expenditure elasticities follow two different patterns. The expenditure elasticities increase with an increase in income for meat and cereals, while, the expenditure elasticities decreased with an increase in income for pulses, dairy products and fruits/vegetables.

The above mentioned consumption pattern of BISP beneficiaries showed that their direct concern is to consume a commodity up to a minimum desired level. Once beneficiaries achieve that desired level, their expenditure share out of total expenditure on that commodity declines with the increase in income. But if this increase in income continues, beneficiaries may switch to better quality of the commodity and thus expenditure on that commodity increases once again.

Table 4: Expenditure Elasticities of BISP Beneficiaries in District Mardan

\begin{tabular}{|c|c|c|}
\hline Food Groups & $\begin{array}{c}\text { Expenditure Elasticities With- } \\
\text { out Cash Income }\end{array}$ & $\begin{array}{c}\text { Expenditure Elasticities With } \\
\text { Cash Income }\end{array}$ \\
\hline Cereals & $0.961^{*}$ & $0.990^{*}$ \\
\hline Dairy & $0.582^{*}$ & $0.558^{*}$ \\
\hline Pulses & $0.611^{*}$ & $0.560^{*}$ \\
\hline Meat & $0.953^{*}$ & $0.977^{*}$ \\
\hline Fruits/vegetable & $0.130^{*}$ & $0.073^{*}$ \\
\hline
\end{tabular}

Source: Author computation from survey data 2016

* indicates significance level at 10\%

\subsubsection{Results for cash transfers and households poverty}

The commodity specific poverty indices of beneficiaries were computed by using the poverty index based on Engel curve. For this purpose food expenditure data 
consisting of five food categories i.e. cereals, meat, pulses, dairy products and fruits/ vegetables were utilized ( See Table A1, A2, A3 in Appendix-A for details about food groups). The cereal has been chosen as a specific commodity while other four groups were taken as composite commodities, because cereal is the most important commodity amongst all five food groups. It shows the highest expenditure elasticity and major share of budget is going to expenditure on cereals. The expenditure on cereals in the study area is below the minimum required level. As income increases beneficiaries spend a major portion of their income on cereals, reaches a saturation level and then decline. This saturation level is used as poverty threshold level. Engel curve was estimated for these five commodity groups and based on the estimated $\mathrm{v}$ and $\mathrm{k}$ parameters the poverty indices were computed. The estimates of the parameters are given in table 5 as below.

Table 5: Estimated Parameters of Engel Curve for the Poverty Index

\begin{tabular}{|c|c|c|}
\hline $\mathrm{V}_{1}$ & $\mathrm{~K}_{1}$ & $\mathrm{~V}_{\mathrm{1}} / \mathrm{K}_{1}$ \\
\hline 2871.62 & 2125.5861 & 2871.62 \\
\hline
\end{tabular}

Source: Author computation from survey data, 2016

Parameters of cereal deprivation poverty index based on Engel curve

Table 5 shows estimated parameters of Engel Curve. Here is the saturation level of expenditure for cereals. The parameter has the interpretation of an income gap. It can be easily verified that corresponds to the level of income needed to consume half of. As can be verified from equation 1, the proportion of expenditure spent on the specific commodity turns out to be. This proportion become as income reaches to zero. Thus is the limiting proportion of expenditure on a specific commodity. It shows that expenditure on cereals is below the saturation level at limiting income. These results showed that most of the beneficiaries are poor and after receiving cash transfer they increase spending on basic necessities.

Similarly, Table 6 below shows the estimates of poverty based on consumption deprivation poverty index. The results in the table showed that severity of poverty is reflected by the commodity specific poverty index associated with the most essential group of commodities i.e. cereals.

Table 6: Estimated Poverty level of Beneficiaries Before and After Cash Transfer

\begin{tabular}{|c|c|c|c|c|}
\hline Per Capita Levels & Before & After & T. test & Sig(2-tailed) \\
\hline $\begin{array}{c}\text { Consumption } \\
\text { shortfall }\end{array}$ & 0.2175 & 0.1473 & 39.220 & .000 \\
\hline Cereals demand & 0.2029 & 0.2261 & -10.674 & .000 \\
\hline Poverty level & 0.4252 & 0.3160 & 89.715 & .000 \\
\hline
\end{tabular}

Source: Author computation from survey data, 2016 
The cereal based poverty index clearly shows that there is a greater incidence of poverty amongst the beneficiaries in the study area. Before cash transfer, beneficiaries were facing consumption shortfall of basic food items which is $21 \%$. This shows that beneficiaries were consuming basic food items below their required level. After receiving cash amount, their consumption shortfall decreased to $14 \%$, their demand for cereals increased from $20 \%$ to $22 \%$, and consumption deprivation reduced from $42 \%$ to $31 \%$. These results showed that beneficiaries were consuming basic food items below their required level. But as they received cash amount their consumption shortfall decreased and their demand for cereals increased, leading to reduction in their consumption poverty. These findings are in line with the results of, Nayab and Farooq (2014) who reached to similar conclusion while examining the role of BISP social protection programme in the households' food consumption and poverty alleviation in Pakistan.

Overall, the findings of the study shows that with the rise in government cash distribution, households income will undeniably increase and thereby their food consumption. Several prior studies empirically examined and vindicated the effects of cash transfers on the share of consumption that is devoted to food at various levels of total consumption through food Engel curve (Fiszbein, Schady \& Ferreira2009; Adato \& Bassett, 2012; Alderman, 2014; Agostino, Scarlato \& Napolitano,2018). These studies observes that, if households considered cash transfer as any other source of income, that transfers move them along the food Engel curve. Moreover, cash transfers directly upsurge households' food spending and that low income families pooled grant money with other income sources to meet their broader needs. Results of this study are also in line with the findings of Hanlon, Armando and David (2010: 167) "The rapid spread of (conditional) cash transfer schemes to at least 45 countries in the Global South has spurred an almost explosive interest in cash-based solutions to continuing poverty in the developing world from scholars and policy-makers alike - and for good reasons............. In the long run, positive investments in education and child health are expected to generate long-lasting human development and drive local (and national) economies forward." In a similar vein, the study of Armando and David (2010):

The rapid spread of (conditional) cash transfer schemes to at least 45 countries in the Global South has spurred an almost explosive interest in cash-based solutions to continuing poverty in the developing world from scholars and policy-makers alike - and for good reasons.............. In the long run, positive investments in education and child health are expected to generate long-lasting human development and drive local (and national) economies forward. (p. 167)

In a similar vein, the study of Dolberg (2012) noted that: 
If partly the aim of the transfer is to encourage self-sufficiency - for example by beneficiaries investing in productive capital for their farms, establishing small businesses, finding paid labour, etc. (which can stimulate pro-poor growth) - some targeting categories are better equipped to serve this objective. The disabled and the old are obviously less likely to become self-supporting. (p. 7)

Thus it can safely be inferred from the above results obtained based the Engel Curve Theory that cash distribution through Benazir Income Support Program by the government of Khyber Pakhtunkhwa is a good policy option to stimulate consumption of the deprived people and thereby reduce poverty which ultimately leads to improve the social welfare of the society.

\section{Conclusion}

The study analyzed the impact of Benazir Income Support Program, Unconditional Cash Transfers (UCT) on food consumption and poverty in the District Mardan. First, it has been investigated whether cash transfers influence household food consumption pattern. The second objective was to estimate the effect of unconditional cash transfers on households' poverty. To achieve the objectives, data has been collected through a well structured questionnaire from 383 beneficiaries who belong to two selected villages, i.e. Kot Doulat Zai and Batagram of the District Mardan. Flexible Linear Approximate Almost Ideal Demand (LA-AIDS) has been used for analyzing the relationship between cash transfers and consumption. After that poverty index has been applied for examining the relationship between cash transfers and consumption deprivation poverty.

The findings revealed that both compensated and uncompensated own and cross price elasticities and expenditure elasticities turned significant with the expected signs. BISP cash transfer increased beneficiaries' expenditures on cereals and meat while decreased on pulses, dairy products and fruits/vegetables. Similarly, analyzing the relationship between cash transfers and poverty of beneficiaries, it is concluded that the consumption shortfall of the households decreased from $21 \%$ to $14 \%$. Furthermore, their consumption deprivation poverty decreased from $42 \%$ to $31 \%$ after receiving the cash. These results showed that the government should increase the amount of cash transfer to enable the beneficiaries to meet their basic food needs. Moreover, the high elastic expenditure and price elasticities of cereals and meat show the importance of these food items for BISP beneficiaries. Along with the income support programme, the government should provide these items at cheaper rates to them. Moreover, the major share of household budget is devoted to cereals, i.e. $46 \%$. This suggests that nutritional requirement gets improved with the availability 
of these food items showing that the programme should launch food grants as well. Education attainment is correlated with the information of better diet which in turn affects nutritional status. The government should also improve its Waseela-e- Taleem Project. Overall, the results show that policies aiming to increase household income will bring substantial improvements in their quality and quantity of food availability. The Unconditional Cash Transfers programme reduced both income and expenditure poverty and increased per capita income and food expenditure. However, proper mechanism should be adopted for this and budget allocation for the programme should be increased for supporting the beneficiaries' education, health and food requirements. This will contribute towards the maximal social protection and welfare of the people of the province of Khyber Pakhtunkhwa.

\section{Limitations of the Study}

Due to limited time period and financial constraints, this study is confined to two villages, namely, Kot Doulat Zai and Batagram of District Mardan.

\section{Future Recommendations}

This study is based on a comprehensive analysis of the role of BISP cash transfer programme in the food consumption and poverty reduction of two selected villages of the District Mardan. Similarly, representative samples from selected union councils of other districts of the Khyber Pakhtunkhwa will provide clearer pictures of the effectiveness of the BISP cash transfer programme in the province.

Future studies can also utilize more advanced econometric techniques which can be another extension in the scope of this study. The other studies can also carry out a comparative analysis of the different social welfare schemes of the government of Pakistan, i.e. BISP Cash Transfer, Zakat, Pension, etc. for highlighting the role of social protection programs in the living standards of the poor and the needy people in the country.

\section{References}

Adato, M., and Bassett, L. (2012). Social protection and cash transfers to strengthen families affected by HIV and AIDS. International Food Policy Research Institute, Washington DC, USA, ISBN: 9780896292017.

Agbaam, C. \& Dinbabo, M. F. (2014). Social grants and poverty reduction at household level: Empirical evidence from Ghana. Journal of Social Science, 39(3), 293-302.

Agbola, F. (2003). Estimation of food demand patterns in South Africa based on a survey of households. Journal of Agriculture Eु Applied Economics, 35, 663-70. 
Agostino, G., Scarlato, M., \& Napolitano, S. (2018). Do cash transfers promote food security? The case of the South African child support grant. Journal of African Economies, 27(4), 430-456.

Alderman, H. (2014). Can transfer programs be made more nutrition sensitive? IFPRI Discussion Paper, 01342 April. Washington DC, USA.

Ambler, K. \& Brauw, A. D. (2017). The impacts of cash transfers on women's empowerment: Learning from Pakistan's BISP programme. World Bank Discussion Paper, 1702.

Angelucci, M., Attanasio, O., \& Maro, V. D. (2012).The impact of oportunidades on consumption, savings and transfers. Fiscal Studies, 33(3), 305-334.

Arnold, C., Conway, T., \& Greenslade, M. (2011). Cash transfers literature review. Department for International Development [DFID], London UK.

Attanasio, O., \& Mesnard, A. (2006). The impact of a conditional cash transfer program on consumption. Journal of Fiscal studies, 27(4), 421-442.

Azam, M., Iqbal, N., \& Tayyab, M. (2014). Zakat and economic development: Micro and macro level evidence from Pakistan., Journal of Bulletin of Business and Economics, 3(2),85-95.

Barrientos, J., Velilla, E., Orozco, D. T., Villada, F., \& Lezama, J. M. L. (2018).On the estimation of the price elasticity of electricity demand in the manufacturing industry of Colombia. Lecturas de Economía, 88, 155-182.

Chavas, J. P., \& Yeung, M. L. (1982). Effects of food stamp program on food consumption in United States., Southeren Journel of Agricultural Economics, 14(1), 31-139.

Coung, N. V., \& Berg, M. V. (2011). Impact of public and private cash transfers on poverty and inequality: Evidence from Vietnam., Development Policy Review , 29(6), 689-728.

Cochran, W.G. (1977). Sampling techniques (3 ${ }^{\text {rd }}$ ed.). John Wiley \& Sons, ISBN: 0-471-16240-X.

Deaton, A., \& Muellbauer, J. (1980). An almost ideal demand system. The American Economic Review, 70(3), 312-326.

Dolberg, F. (2012). Cash transfers - A viable approach to development. Retrieved from http://citeseerx.ist. psu.edu/viewdoc/download?doi=10.1.1.472.8035\& rep=rep1\&type=pdf

Ezemenari, K., \& Subbarao, K. (1998). Jamacia food stamp programme: Impacts on poverty and welfare. World Bank Policy Reserach Working Paper, No.2207, 1-42.

Fiszbein, A., Schady, N. R., and Ferreira, F. H. (2009). Conditional cash transfers: reducing present and future poverty. World Bank Publications.

Government of Pakistan (2012). Household Integrated Economic Survey, Pakistan Bureau of Statistics, Islamabad.

Government of Pakistan (2015A). Annual Plan 2015-16. Ministry of Planning, Development and Reform. 
Government of Pakistan (2015B). Pakistan Economic Survey 2014-15. Ministry of Finance, Economic Advisor's Wing, Islamabad.

Government of Pakistan (2017). Unconditional cash transfers, Benazir Income Support Programme. Retrieved from http:// http://bisp.gov.pk/cash-grant/\#background946d-4435.

Hanlon, J., Armando, B. \& David, H. (2010). Just give money to the poor. The Development Revolution from the Global South.United States: Kumarian Press.

Hassan, S. M. (2015). Making an impact? Analysis of social protection programs in Pakistan. Journal of Research Society of Pakistan, 52(1), 201-210.

Hjelm, L., Handa, S., de Hoop, J., Palermo, T., Zambia, C. G. P., \& Teams, M. E. (2017). Poverty and perceived stress: Evidence from two unconditional cash transfer programs in Zambia. Social Science $\mathcal{G}$ Medicine, 177, 110-117.

Holmes, R., \& Bhuvanendrah, D. (2013). Social protection and resilient food systems: The role of cash transfers. Annual Report, Overseas Development Institute, London, UK.

Honorati, M., Gentilini, U. \& Yemtsov, R.G. (2015). The state of social safety nets 2015. World Bank Report No. 97882,Washington DC, doi:10.1596/978-1-4648-0543-1.

Huang, C. L., Fletcher, S. M., \& Raunikar, R. (1981).Modeling the effects of the Food Stamp Program on participating households' purchases: An empirical application. Journal of Agricultural and Applied Economics, 13(2), 21-28.

Kaul, T. (2018). Household responses to food subsidies. Economic Development and Cultural Change, 67(1),95-129.

Khan, T., \& Hasan, M. M. (2016). Social protection system in Bangladesh and the scope of social work: learning from lessons on the ground. MPRA Paper No. 70949.

Khan, S., Akhtar, D.S., Khan, D. N., \& Adnan, A. (2017).The role of cash grant scheme of Benizir Income Support Program in poverty alleviation in the rural areas of district Mardan: A case study of three selected villages of district Mardan. Research on Humanities and Social Sciences, 7(3), 45-50.

Lesser, C. E. V. (1963).Forms of Engel functions. Econometrica, 31, 694-703.

Maitra, P., \& Ray, R. (2003). The effect of transfers on household expenditure pattern and poverty in South Africa. Journal of Development Economics, 71(3), 23-49.

Malik, Z. A., Kiran, S., \& Alam, M. (2013). The role of Benazir income support program in poverty reduction: A case study of the selected villages in District Peshawar. City University Research Journal, 3(1),35-45.

Meng, Y., Brennan, A., Purshouse, R., Hill-McManus, D., Angus, C., Holmes, J., \&Meyer, P.S. (2014). Estimation of own and cross price elasticities of alcohol demand in the UK: A pseudo-panel approach using the living costs and food survey 2001-2009, Journal of Health Economics, 34, 96-103. 
Naqvi, M. A., Sabir, H. M., Shamim, A., \& Tariq, M. (2014). Social saftey nets and poverty in Pakistan (A case study of BISP in Tehsil Manakera District Bhakar. Journal of Finance and Economics, 2(2),44-49.

Nayab, D., \& Farooq, S. (2014). Effectiveness of cash transfer programs for household welfare

in Pakistan: The case of Benazir Income Support Program. The Pakistan Development Review, 53(2), 145-174.

Neenan, P. H., \& Davis, C. G. (1977). Impact of food stamp program on low income household food consumption in rural Florida. Southrren Journal of Agricultural Economics, 9(3), 89-97.

Phillips, K. S., \& Price, D. W. (1982). A comparative theoretical analysis of the impact of the food stamp programme as opposed to cash transfer on the demand for food.Western Journal of Agricultural Economics, 7(1), 53-66.

Pollak, R. A., \& Wales, T. J. (1978). Estimation of complete demand systems from household budget data: the linear and quadratic expenditure systems. The American Economic Review, 68(3), 348-359.

Prais, S. J., \& Houthakker, H. S. (1971). The analysis of family budgets. University of Cambridge, Department of Applied Economics, Monograph 4.

Rawlings, L. B., \& Rubio, M. G. (2003). Evaluating the impact of conditional cash transfer programmes in Latin America. World Bank Policy Research, Working Paper. No.3119,1-25.

Shehzad, I. (2011). Benazir Income Support Program and its impact on women's empowerment. SAARC Journal of Human Resource Development, 7(1), 71-81.

Skoufias, E., \& Maro, V. D. (2006). Conditional cash transfer, adult work incentives and poverty. World Bank Policy Research Working Paper. No. 3973,1-38.

Tabor, S. R. (2002). Assisting the poor with cash: Design and implementation of social transfer program in middle income countries. Social Discussion Paper Series, No. 0223.

Tiwari, S., Ruvalcaba, M. A., Prifti, E., Handa, S., Devis, B., Niang, O., Pellerano, L., Ufford, P. Q., \& Seidenfeld, D. (2016). Impact of cash transfer programmes on food security and nutrition in Sub-Saharan Africa: a cross-country analysis. Global Food Security, 11, 72-83.

Van de Walle, D. (2002). The static and dynamic incidence of Vietnam's public safety net. World Bank, Policy Research Working Paper No. 2791, Washington DC, USA.

Walpole, R. (1982). Introduction to statistics (3 ${ }^{\text {rd }}$ ed.). New York: Macmillan, 277-278.

Working, H. (1943). Statistical laws of family expenditures. Journal of the American Statistical Association, $38,43-56$. 


\section{APPENDIX-A}

Table A1: General Price Level of Selected Food Items in District Mardan

\begin{tabular}{|c|c|c|c|}
\hline Food groups & Prices & Food groups & Prices \\
\hline Cereals & 682 & Fruit \& Vegetables & 1250 \\
\hline Wheat flour & 42 & Apple & 170 \\
\hline Rice & 100 & Banana & 120 \\
\hline Maize & 480 & Grapes & 160 \\
\hline Suji/Maida/Besan & 60 & Guava & 60 \\
\hline Dairy Products & 3219 & Orange & 160 \\
\hline Fresh milk & 80 & Dates & 120 \\
\hline Milk packed & 110 & Other/Kino & 40 \\
\hline Milk powdered & 790 & Ladyfinger & 100 \\
\hline Yoghurt/lassie & 225 & Cabbage/Cauliflower & 20 \\
\hline Butter/cheese/cream & 1364 & Tomato & 30 \\
\hline Pulses & 830 & Onion & 40 \\
\hline Dal Chana & 130 & Potato & 20 \\
\hline Moong & 140 & Sag & 30 \\
\hline Masoor & 150 & Tinda & 50 \\
\hline Mash dal & 260 & Peas & 60 \\
\hline Other dal/beans & 150 & Carrot/green chilies & 20 \\
\hline Meat & 1300 & - & - \\
\hline Beef & 350 & - & $\cdots$ \\
\hline Mutton & 500 & $\ldots$ & 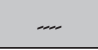 \\
\hline Chicken & 150 & - & $\cdots$ \\
\hline Fish & 300 & $m$ & $m$ \\
\hline
\end{tabular}

Source: Field Survey Data, 2016

Prices are given in rupees per kilo gram 
Table A2: Categorization of Food Items

\begin{tabular}{|c|c|}
\hline Selected Food Groups & Selected Food Items in Food Groups \\
\hline Cereals & Wheat flour, rice, maize, suji/maida/besan \\
\hline Dairy & $\begin{array}{c}\text { Milk pack, fresh milk, milk powdered, yoghurt/lassie, cream/cheese/ } \\
\text { butter }\end{array}$ \\
\hline Meat & Beef, mutton, chicken, fish \\
\hline Fruits/Vegetables & $\begin{array}{c}\text { Apple, banana, Kino. Orange ,dates, grapes ,guava, ladyfinger, potato, } \\
\text { cabbage, cauliflower, tomato ,onion sag ,pumpkin , peas tinda, carrot } \\
\text { green chilies }\end{array}$ \\
\hline Pulses & Dal chana, moong dal, masoor dal. Mash dal other dal/beans \\
\hline
\end{tabular}

Table A3: Household Budget Share on Various Food Items

\begin{tabular}{|c|c|}
\hline Food Groups & Households Mean Budget Share \\
\hline Cereals & 0.47 \\
\hline Dairy & 0.23 \\
\hline Pulses & 0.069 \\
\hline Meat & 0.10 \\
\hline Fruits/Vegetables & 012 \\
\hline
\end{tabular}

Source: Field Survey, 2016 